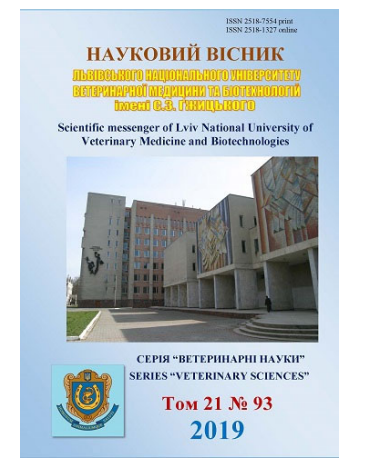

\author{
Науковий вісник Дьвівського національного університету \\ ветеринарної медицини та біотехнологій імені С.3. Гжицького. \\ Серія: Ветеринарні науки \\ Scientific Messenger of Lviv National University \\ of Veterinary Medicine and Biotechnologies. \\ Series: Veterinary sciences
}

UDC 636.598.09:616.995.1

\title{
Therapeutic effectiveness of modern antihelminthic drugs for geese capillariasis
}

\author{
V.O. Yevstafieva, V.I. Yeresko \\ Poltava State Agrarian Academy, Poltava, Ukraine
}

Article info

Received 21.01.2019

Received in revised form 01.03.2019

Accepted 02.03.2019

Poltava State Agrarian Academy, Skovorody Str., 1/3, Poltava, 36003, Ukraine.

Tel.:+38-050-183-78-78

E-mail:evstva@ukr.net

Yevstafieva, V.O., \& Yeresko, V.I. (2019). Therapeutic effectiveness of modern antihelminthic drugs for geese capillariasis. Scientific Messenger of Lviv National University of Veterinary Medicine and Biotechnologies. Series: Veterinary sciences, 21(93), 41-45. doi: 10.32718/nvlvet9308

Many years of experience in fighting and preventing of helminthiasis in waterfowl shows that the successful elimination of parasitic diseases is possible under the conditions of a complex of organizational and economic, veterinary and sanitary and special anti-parasitic measures, which must necessarily include deworming of poultry. The purpose of the work was to study the effectiveness of modern antihelminthic drugs for the spontaneous capillariasis geese. Experimental testing of antihelminthic preparations of domestic production was performed: piperazine $45 \%$ (DR - piperazine adipinat), $22 \%$ phenzole (DR - fenbendazole) and brovadazole plus (DR - piperazine adipinat, phenbendazole). The efficacy of the drugs was determined by the results of helminthic autopsy and coproscopicof the geese of the experimental and control groups. The main indicators of the action of drugs were extensiveness and intensive. It was established that according to the results of helminthocoproscopic investigations, the most effective drugs for capillariasis geese were phenzole $22 \%$ and brovadazole plus, their effectiveness at day 15 of the experiment was $100.0 \%$. Efficiency (EE and IE) of piperazine $45 \%$ was slightly lower and at day 5 of treatment, according to the results of the coproscopy, was $40.0 \%$ and $65.0 \%$ respectively, for 10 days $-70.0 \%$ and $76.0 \%$, for 15 days $70 \%, 0$ and $82.0 \%$. At the same time, according to the results of helminthic autopsy geese in the process of their treatment, the effectiveness of the preparations of phenzole $22 \%$ and piperazine $45 \%$ were lower. EI of experimental geese for 15 days with the use of phenzole $22 \%$ was $40.0 \%$, and II decreased from $21.20 \pm$ 1.16 to $2.00 \pm 1.00 \mathrm{ex}$./head. In the application of piperazine, $45 \%$ of the experimental poultry EI for 15 days reached $60.0 \%$, II decreased from $22.40 \pm 1.12$ to $3.67 \pm 0.58$ ex./head. Extens- and intensefficiency of piperazine $45 \%$ was 40.0 and $86.0 \%$, phenzole $22 \%-60.0$ and $92.0 \%$, respectively. It was determined that the most effective preparation for geese capillariasis is brovadazole plus (EE, IE - 100.0\%), which is confirmed by the results of coproscopic studies and helminthic autopsy. Based on the data obtained, confirmed by experimental studies, we recommend the use of the drug brovadazol plus in the control and prevention of capillariasis geese.

Key words: geese, capillariasis, treatment, antihelmintic preparations, efficacy, coproscopy, helminthic autopsy.

\section{Терапевтична ефективність сучасних антигельмінтних препаратів за капіляріозу гусей}

\author{
В.О. Свстаф’єва, В.І. Єресько
}

Полтавська державна аграрна академія, м. Полтава, Україна

Багаторічний досвід боротьби та профілактики за гельмінтозів водоплавної птиці свідчить, щчо успішна ліквідація паразитарних захворювань можлива за умов виконання комплексу організаційно-господарських, ветеринарно-санітарних і спечіальних протипаразитарних заходів, які обов'язково повинні включати дегельмінтизачію птиці. Метою роботи було вивчити ефективність сучасних антигельмінтних препаратів за спонтанного капіляріозу гусей. Проведено експериментальне випробування антигельмінтних препаратів вітчизняного виробництва: піперазину 45\% (ДР - піперазину адипінат), фензолу 22\% (ДР - фенбендазол) та 
бровадазолу плюс (ДР - піперазину адипінат, фенбендазол). Ефективність препаратів визначали за результатами гельмінтологічного розтину та копроскопічних досліджень гусей дослідних та контрольної груп. Головними показниками дії препаратів були екстенсефективність та інтенсефективність. Встановлено, шуо за результатами гельмінтокопроскопічних досліджень найбільш ефективними препаратами за капіляріозу гусей виявилися фензол 22\% та бровадазол плюс, їх ефективність на 15 добу експерименту становила 100,0\%. Ефективність (EE та IE) піперазину 45\% виявилася дещзо нижчою і на 5 добу лікування за результатами копроскопї становила, відповідно 40,0 та 65,0\%, на 10 добу - 70,0 та 76,0\%, на 15 добу - 70,0 та 82,0\%. Водночас, за результатами гельмінтологічного розтину гусей у процесі їх лікування, показники ефективності препаратів фензолу 22\% та піперазину 45\% були нижчими. ЕІ дослідних гусей на 15 добу при застосуванні фензолу 22\% становила 40,0\%, а II знизилася з 21,20 $\pm 1,16$ до 2,00 $\pm 1,00$ екз./гол. При застосуванні піперазину 45\% дослідній птииі ЕІ на 15 добу сягала 60,0\%, а II знизилася з $22,40 \pm 1,12$ до 3,67 \pm 0,58 екз./гол. Екстенс- та інтенсефективність піперазину 45\% становили 40,0 і 86,0\%, фензолу 22\% - 60,0 і 92,0\% відповідно. Визначено, шзо найефективнішим препаратом за капіляріозу гусей є бровадазол плюс (ЕE, IE - $100,0 \%)$, шзо підтверджується результатами копроскопічних досліджень та гельмінтологічного розтину. На основі отриманих даних, ио підтверджені експериментальними дослідженнями, рекомендуємо застосовувати препарат бровадазол плюс у боротьбі та профілактиці за капіляріозу гусей.

Ключові слова: гуси, капіляріоз, лікування, антигельмінті препарати, ефективність, копроскопія, гельмінтологічний розтин.

\section{Вступ}

Більшість авторів стверджують, що успішна боротьба $з$ паразитарними хворобами сільськогосподарської птиці можлива лише за умов проведення комплексних заходів, які включають суворе дотримання сучасних технологій ведення птахівництва, а також за наявності високоефективних лікарських засобів в системі хіміотерапії. Важливим є і залишається застосування високоефективних, малотоксичних, дешевих, зручних при введенні, з широким спектром дії лікувальних засобів (Sharma et al., 1990; Tucker et al., 2007; Javid et al., 2013; Raza et al., 2016).

Однак останнім часом науковці зазначають, що більшість із антигельмінтиків у терапевтичних дозах також, як і паразити, $є$ імунодепресантами та мають на організм птахів токсичний вплив (Shumard, 1957; Gartrell et al., 2005; Abbas et al., 2016). Водночас тривале застосування одних і тих же препаратів призводить до розвитку резистентності до них паразитів, що супроводжується зниженням ефективності лікувальних заходів (Condi et al., 2009; James et al., 2009; Bellaw et al., 2018; Pena-Espinoza, 2018).

Тому завжди виникає необхідність досліджувати ефективність лікарського засобу щодо певного виду збудника інвазії птиці незалежно від того - новий це препарат чи такий що вже використовується у господарствах. Це своєю чергою, дозволить встановлювати виникнення опірності збудників до препарату (Mwamachi et al., 1995; Pulaski et al., 2014; Redman et al., 2015).

Згідно з науковими даними, більшість праць присвячено вивченню ефективності лікарських засобів, переважно за капіляріозу суходільної птиці, а також у водоплавної птиці - за асоціативних інвазій, у складі яких є капілярії (Tucker et al., 2007; Ibarra-Velarde et al., 2011; Alaijos and Javier, 2015).

Так, встановлено, що препарати групи бензімідазолів виявилися високоефективними лікарськими засобами за капіляріозу курей: із діючою речовиною альбендазол ефективність коливалася від 90,3 до $100,0 \%$, із ДР фенбендазол - до $100 \%$, із ДР мебендазол - до 99,1\%, із ДР флюбендазол - до 99,4\% (Taylor et al., 1993; Squire et al., 2012).

Інші автори визначили, що за капіляріозу курей ефективність левамізолу становила 90,3-95,8\%, а пірантел тартрату - 77,1-92,3\% (Enigr, 1975). Одночасно доведена $100 \%$ ефективність івермектину та піперазину цитрату за капіляріозної інвазії качок. Хоча застосування фенбендазолу не звільняло птицю від капілярій, ефективність становила 67\% (Islam et al., 2012).

Порівняльне випробування ефективності хіміопрепаратів, проведене у Брянській області, показало, що авертин-порошок 0,2\% у дозі 0,28 мг/кг (за ДР) за одноразової індивідуальної задачі або при його застосуванні дві доби поспіль груповим способом показав високу (100\%) ефективність за капіляріозу гусей. Альбендазол у дозі 10 мг/кг також виявився високоефективним препаратом за капіляріозу гусей (100\%). Водночас ефективність клозальбену-10 (містить в 1 г по 50 мг альбендазолу та клозантелу) у дозі 0,2 г/кг за одноразової індивідуальної задачі водоплавній птиці у формі болюсів за капіляріозу становила $86,7 \pm 8,8 \%$ (Kazachkova, 2003).

Метою роботи було вивчити ефективність сучасних антигельмінтних препаратів за спонтанного капіляріозу гусей.

\section{Матеріал і методи досліджень}

Дослідження проводилися упродовж листопадагрудня 2018 року на базі ТОВ “Шишацьке інкубаторно-птахівниче підприємство” Шишацького району Полтавської області. Паразитологічні дослідження проводили в лабораторії кафедри паразитології та ветеринарно-санітарної експертизи факультету ветеринарної медицини Полтавської державної аграрної академії.

Для дослідів використовували гусей віком понад 9 місяців, спонтанно інвазованих капіляріями. Копроовоскопічні дослідження проводили за методом В.Н. Трача (Trach, 1992). Збір гельмінтів проводили методом повного гельмінтологічного розтину органів травного каналу птиці (Skrjabyn, 1928). Основними показниками ураження гусей гельмінтами були показники екстенсивності (ЕI, \%) та інтенсивності інвазії (II, ЯГП; екз./гол.).

3 метою визначення терапевтичної ефективності антигельмінтиків за капіляріозу було сформовано три дослідних і одна контрольна групи птиці по 10 голів у кожній. Дослідні та контрольна групи гусей протягом 
періоду досліджень перебували в аналогічних умовах годівлі й утримання.

Птиці першої дослідної групи згодовували разом 3 кормом груповим способом "Піперазин 45\%" (ПрАТ "ВНП "Укрзооветпромпостач”, Україна) у дозі 1,0г/кг маси тіла дворазово 3 інтервалом одна доба. Птиці другої дослідної групи згодовували разом 3 кормом груповим способом “Фензол 22\%” (ПрАТ “ВНП “Укрзооветпромпостач”, Україна) у дозі 1,8 г/10 кг маси тіла дві доби поспіль. Птиці третьої дослідної групи згодовували разом 3 кормом груповим способом “Бровадазол плюс" (ТОВ “Бровафарма", Україна) у дозі 2,0 г/10 кг маси тіла дві доби поспіль. Птицю контрольної групи не дегельмінтизували.

Ефективність антигельмінтних препаратів визначали на 5, 10 та 15 добу після останнього їх застосування за результатами копроскопічних досліджень гусей дослідних та контрольної груп. До початку експерименту додатково провели гельмінтологічний розтин 20 гусей 3 метою встановлення інтенсивності інвазії. На 15 добу повторно провели гельмінтологічний розтин гусей по 5 голів 3 кожної групи. Головними показниками дії препаратів були екстенсефективність (ЕЕ) та інтенсефективність (IE).

Математичний аналіз отриманих даних проводили 3 використанням пакета прикладних програм Microsoft "EXCEL" шляхом визначення середнього арифметичного (М) та його похибки (m).

\section{Результати та їх обговорення}

Показники інтенсивності інвазії у дослідних та контрольної групи гусей до початку їх лікування коливалися в межах: за копроскопічними дослідженнями від $114,00 \pm 7,33$ до $122,00 \pm 5,54$ яєць у1 г посліду (ЯГП), за результатами гельмінтологічного розтину від 18 до 27 екз./гол.

Встановлено, що у процесі лікування хворих гусей при порівнянні показників екстенсивності та інтенсивності інвазії, отриманих в результаті застосування методів зажиттєвої та посмертної діагностики, значення ефективності препаратів були різними (рис. 1, 2).

Так, за результатами копроскопії найбільш ефективними препаратами виявилися фензол 22\% та бровадазол плюс, екстенс- та інтенсефективність на 15 добу експерименту становили 100,0\%. Причому при застосуванні бровадазолу плюс вже на 5 добу лікування ЕЕ та IE дорівнювали 100,0\%. При застосуванні хворій птиці фензолу $22 \%$ на 5 добу ЕЕ та IE становили 70,0 та 80,0\% відповідно, а на 10 добу ці показники сягали 100,0\%. Ефективність піперазину $45 \%$ за капіляріозу гусей виявилася дещо нижчою і на 5 добу лікування становила відповідно 40,0 та 65,0\%, на 10 добу - 70,0 та 76,0\%, на 15 добу - 70,0 та 82,0\%.

Водночас, за результатами гельмінтологічного розтину гусей у процесі їх лікування, показники ефективності препаратів фензолу $22 \%$ та піперазину $45 \%$ були нижчими.
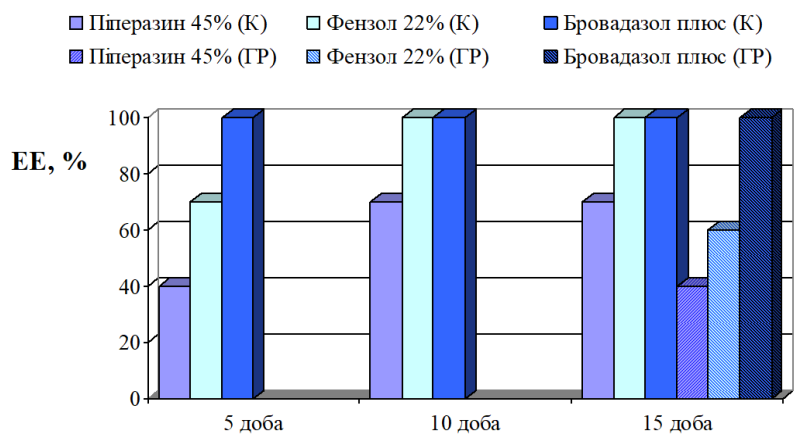

Рис. 1. Показники екстенсефективності антигельмінтних препаратів за капіляріозу гусей: $\mathrm{K}$ - за результатами копроскопічних досліджень; ГР - за результатами гельмінтологічного розтину
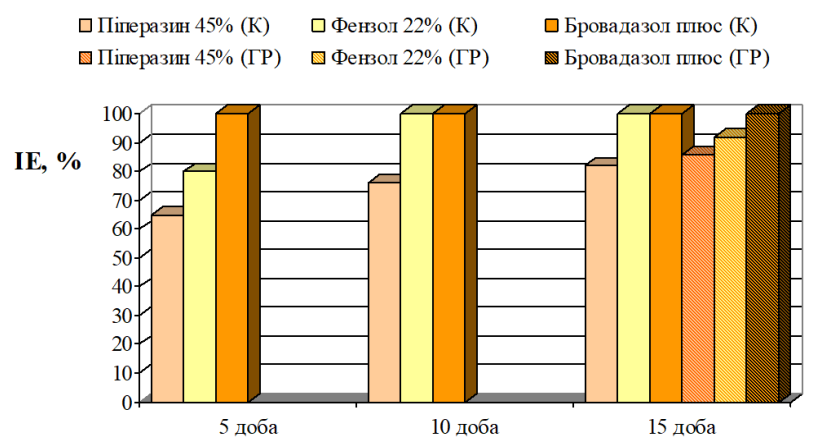

Рис. 2. Показники інтенсефективності антигельмінтних препаратів за капіляріозу гусей: К - за результатами копроскопічних досліджень; ГР - за результатами гельмінтологічного розтину

Так ЕІ дослідних гусей на 15 добу при застосуванні фензолу $22 \%$ становила $40,0 \%$, а II знизилася 3 $21,20 \pm 1,16$ до 2,00 $\pm 1,00$ екз./гол. Водночас при застосуванні піперазину $45 \%$ дослідній птиці ЕI на 15 добу сягала 60,0\%, а II знизилася з 22,40 $\pm 1,12$ до $3,67 \pm 0,58$ екз./гол. Показники екстенс- та інтенсефективності цих становили: піперазину 45\% - 40,0 i $86,0 \%$, фензолу $22 \%-60,0$ і $92,0 \%$.

Визначено, що найефективнішим препаратом за капіляріозу гусей $\epsilon$ бровадазол плюс (EE, IE 100,0\%), що підтверджується результатами копроскопічних досліджень та гельмінтологічного розтину птиці (табл. 1).

Менш ефективними виявився піперазин 45\%, ЕЕ коливалася в межах від 40,0 до 70,0\%, а IE - від 82,0 до $86,0 \%$. Препарат фензол $22 \%$ за результатами копроскопічних досліджень був високоефективним за капіляріозу гусей (EE, IE - 100,0\%). Водночас, за результатами гельмінтологічного розтину, цей препарат показав недостатню ефективність (EE - 60,0\%, IE $-92,0 \%)$.

Аналізуючи отримані дані, можна зазначити, що більшість наукових праць присвячено вивченню ефективності лікарських засобів за капіляріозу суходільної птиці (Ibarra-Velarde et al., 2011; Alaijos and Javier, 2015). Однак визначенню антигельмінтної активності препаратів проти капілярій, що паразитують у водоп- 
лавної птиці, присвячені лише окремі праці (Shevcov, 1967; Kovalenko, 1985).

\section{Таблиця 1}

Терапевтична ефективність антигельмінтних препаратів за капіляріозу гусей

\begin{tabular}{lcccc}
\hline \multirow{2}{*}{ Препарати } & \multicolumn{2}{c}{ EE, \% } & \multicolumn{2}{c}{ IE, \% } \\
\cline { 2 - 5 } & $\mathrm{K}$ & $\Gamma \mathrm{P}$ & $\mathrm{K}$ & $\Gamma \mathrm{P}$ \\
\hline Піперазин 45\% & 70,0 & 40,0 & 82,0 & 86,0 \\
Фензол 22\% & 100,0 & 60,0 & 100,0 & 92,0 \\
Бровадазол плюс & 100,0 & 100,0 & 100,0 & 100,0 \\
\hline
\end{tabular}

Результатами проведених досліджень встановлена висока терапевтична ефективність препарату бровадазол плюс (ДР - піперазину адипінат, фенбендазол) за капіляріозу гусей. На 15 добу після його застосування хворій птиці екстенс- та інтенсефективність становили 100,0\%. Така висока ефективність була підтверджена проведеними результатами копроскопічних досліджень та гельмінтологічного розтину. Водночас ефективність (ЕE, IE) препарату фензол 22\% (ДР фенбендазол) за копроскопічними дослідженнями хворої на капіляріоз птиці становила $100,0 \%$, а за результатами гельмінтологічного розтину дослідних гусей - 60,0 та 92,0\%. На нашу думку, таку різницю у показниках ефективності можна пояснити тим, що копроскопічний метод дослідження не завжди реально відображає дані щодо наявності гельмінтів та їхньої кількості в організмі хазяїна. Так, антигельмінтик може діяти на паразита, як стрес-фактор внаслідок чого припиняється його яйцепродукція, але загибель паразита може і не відбуватися. Препарат піперазин 45\% (ДР - піперазину адипінат) виявився недостатньо ефективним при лікуванні гусей, хворих на капіляріо3. Показники його ефективності залежно від методу дослідження птиці коливалися в межах від 40,0 до $86,0 \%$.

Про недостатню ефективність антигельмінтиків на основі піперазину адипінату та фенбендазолу свідчать наукові праці, в яких при лікуванні птиці за капіляріозу їхня терапевтична ефективність не перевищувала 90,0\% (Shevcov, 1967; Natjagla, 2016).

\section{Висновки}

Високоефективним антигельмінтним препаратом за капіляріозу гусей виявився бровадазол плюс, який містить комбінацію двох діючих речовин - піперазину адипінат і фенбендазол. Його екстенс- та інтенсефективність становили 100,0\%. Окреме застосування препаратів, які містять тільки фенбендазол (фензол $22 \%$ ) або піперазин адипінат (піперазин 45\%), не призводило до повного одужання птиці, їх ефективність коливалася в межах від 40,0 до 92,0\%. Водночас застосування методу гельмінтологічного розтину птиці у процесі експериментального визначення ефективності препаратів є більш достовірним, оскільки дозволяє точно зробити висновок щодо інвазованості птиці гельмінтами.
Перспективи подальших досліджень. Проведені дослідження обумовлюють необхідність визначення економічної доцільності застосування антигельмінтних препаратів, які $є$ високоефективними у боротьбі 3 капіляріозом гусей.

\section{References}

Abbas, G., Rehman, M.Z.U., Ali, A., Fiaz, M., \& Mahfooz, A. (2016). Effect of Use of Different Anthelmintics (Piperazine Citrate and Ivermectine) on Blood Profile of Infested Poultry (Commercial and Rural Layers). Advances in Zoology and Botany, 4(1), 1-5. doi: 10.13189/azb.2016.040101.

Alaijos, O.R., \& Javier, R.F. (2015). The Antihelminthic Efficacy of Artemisia Capillaris in Free-Range Chickens Naturally Infected with Ascaridia Galli, Capillaria Spp and Strongyloides Spp. International Journal of Life Sciences Research, 3(3), 20-22.

Bellaw, J.L., Krebs, K., Reinemeyer, C.R., Norris, J.K., Scare, J.A., Pagano, S., \& Nielsen, M.K. (2018). Anthelmintic therapy of equine cyathostomin nematodes-larvicidal efficacy, egg reappearance period, and drug resistance. International Journal for Parasitology, 48(2), 97-105. doi: 10.1016/ j.ijpara.2017.08.009.

Condi, G., Soutello, R., \& Amarante, A. (2009). Moxidectin-resistant nematodes in cattle in Brazil. Veterinary Parasitology, 161(3-4), 213-217. doi: 10.1016/j.vetpar.2009.01.031.

Enigr, K. (1975). Die Behandiung des Hausgefluges. Tierarztl Umsch, 30(7), 324-329.

Gartrell, B.D., Alley, M.R., \& Mitchell, A.H. (2005). Fatal levamisole toxicosis of captive kiwi (Apteryx mantelli). New Zealand Veterinary Journal, 53(1), 8486. doi: 10.1080/00480169.2005.36474.

Ibarra-Velarde, F., Guerrero-Molina, C., VeraMontenegro, Y., Alcalá-Canto, Y., \& RomeroCallejas, E. (2011). Comparison of the anthelmintic efficacy of three commercial products against ascarids and capillaria spp. in fighting cocks. Journal of Pharmacy and Pharmacology, 2(3), 146-150. doi: 10.4236/pp.2011.23020.

Islam, A., Anisuzzaman, Majumder, S., Islam, M.A., Rabbi, A.K.M.A., \& Rahman, M.H. (2012). Efficacy of anthelmintics against nematodes in naturally infected free range ducks. Eurasian Journal of Veterinary Sciences, 28(4), 229-232. http://eurasianjvetsci.org/pdf/pdf_EJVS_976.pdf.

James, C.E., Hudson, A.L., \& Davey, M.W. (2009). Drug resistance mechanisms in helminths: is it survival of the fittest? Trends in Parasitology, 25(7), 328-335. doi: 10.1016/j.pt.2009.04.004.

Javid, A., Syed, T. \& Bilal, A.Z. (2013) In vitro anthelmintic activity of Mentha longifolia (L.) leaves against Ascaridia galli. Global Veterinaria, 11(1), 112-117. doi: 10.1017/S0043933915002615.

Kazachkova, R.V. (2003). Gelmintofauna vodoplavajushhih ptic Brjanskoj oblasti i mery borby 
s osnovnymi gelmintozami (Diss. kand. vet. nauk). Moskva (in Russian).

Kovalenko, I.I. (1985). Panakur kur i gusej. Veterinarija, 8, 42-43 (in Russian).

Mwamachi, D.M., Audho, J.O., Thorpe, W., \& Baker, R.L. (1995). Evidence for multiple anthelmintic resistance in sheep and goats reared under the same management in coastal Kenya. Veterinary Parasitology, 60(3-4), 303-313. doi: 10.1016/03044017(95)00794-1.

Natjagla, I.V. (2016). Likuvalna efektyvnist antygelmintnyh preparativ za kapiljariozu kurej. Naukovo-tehnichnyj bjuleten' NDC biobezpeky ta ekologichnogo kontrolju resursiv APK, 4(3), 65-68. Retrieved from http://www.biosafety-center.dp.ua (in Ukrainian).

Pena-Espinoza, M. (2018). Drug resistance in parasitic helminths of veterinary importance in Chile: Status review and research needs. Austral Journal of Veterinary Sciences, 50(2), 65-76. doi: 10.4067/S0719-81322018000200065.

Pulaski, C.N., Malone, J.B., Bourguinat, C., Prichard, R., Geary, T., Ward, D., Klei, T. R., Guidry, T., Smith, G., Delcambre, B., Bova, J., Pepping, J., Carmichael, J., Schenker, R., \& Pariaut, R. (2014). Establishment of macrocyclic lactone resistant Dirofilaria immitis isolates in experimentally infected laboratory dogs. Parasites and Vectors, 7, 494. doi: 10.1186/s13071014-0494-6.

Raza, A., Muhammad, F., Bashir, S., \& Aslam, B. (2016). In-vitro and in-vivo anthelmintic potential of different medicinal plants against Ascaridia galli infection in poultry birds. World's Poultry Science Journal, 72(1), 115-124. doi: 10.1017/S0043933915002615.

Redman, E., Whitelaw, F., Tait, A., Burgess, C., Bartley, Y., Skuce, P.J., Jackson, F., \& Gilleard, J.S. (2015). The emergence of resistance to the benzimidazole anthlemintics in parasitic nematodes of livestock is characterised by multiple independent hard and soft selective sweeps. PLOS Neglected Tropical Diseases, 9(2), e0003494. doi: 10.1371/journal.pntd.0003494.

Sharma, R.L., Bhat, T.K., \& Hemaprasanth (1990). Anthelmintic activity of ivermectin against experimental Ascaridia galli infection in chickens. Veterinary Parasitology, 37(3-4), 307-314. doi: 10.1016/0304-4017(90)90014-3.

Shevcov, A.A. (1967). Opyt ozdorovlenija pticy ot gelmintozov. Veterinarija, 5, 81-82 (in Russian).

Shumard, R.F. (1957). The Toxicity to Chickens and the Anthelmintic Effect of Two Forms of a Piperazine-Carbon Disulfide Complex on Ascaridia galli and Heterakis gallinae. Poultry Science, 36(3), 613-618. doi: 10.3382/ps.0360613.

Skrjabin, K.I. (1928). Metod polnyh gel'mintologicheskih vskrytij pozvonochnyh, vkljuchaja cheloveka. Moskva (in Russian).

Squires, S., Fisher, M., Gladstone, O., Rogerson, S., Martin, P., Martin, S., Lester, H., Sygall, R., \& Underwood, N. (2012). Comparative efficacy of flubendazole and a commercially available herbal wormer against natural infections of Ascaridia galli, Heterakis gallinarum and intestinal Capillaria spp. in chickens. Veterinary Parasitology, 185(2-4), 352-354. doi: 10.1016/j.vetpar.2011.09.034.

Taylor, S.M., Kenny, J., Houston, A., \& Hewitt, S.A. (1993). Efficacy, pharmacokinetics and effects on egg-laying and hatchability of two dose rates of infeed fenbendazole for the treatment of Capillaria species infections in chickens. Veterinary Record, 133(21), 519-521. doi: 10.1136/vr.133.21.519.

Trach, V.N. (1992). Rekomendacii po primeneniju novogo metoda ucheta jaic gelmintov i cist prostejshih v fekalijah zhivotnyh. Kiev (in Russian).

Tucker, C.A., Yazwinski, T.A., Reynolds, L., Johnson, Z., \& Keating, M. (2007). Determination of the anthelmintic efficacy of albendazole in the treatment of chicken naturally infected with gastrointestinal helminthes. Journal of Applied Poultry Research, 16(3), 392-396. doi: 10.1093/japr/16.3.392. 